\title{
Influenza elleni védőoltás: mi szól mellette és ellene?
}

\author{
Háziorvosok és a lakosság nézetei
}

\author{
Eörsi Dániel dr. ${ }^{1,2}$ - Gács Zsófia dr. ${ }^{3}$ - Kun Eszter ${ }^{4}$ \\ ${ }^{1}$ Semmelweis Egyetem, Általános Orvostudományi Kar, Népegészségtani Intézet, Budapest \\ ${ }^{2}$ Iatoria Egészségügyi Szolgálat, Budapest \\ ${ }^{3}$ Semmelweis Egyetem, Általános Orvostudományi Kar, II. Gyermekgyógyászati Klinika, Budapest \\ ${ }^{4}$ Szinapszis Piackutató és Tanácsadó Kft., Budapest - Debrecen
}

\begin{abstract}
Bevezetés: A magyar felnőtt lakosság heterogén attitűdje folytán az influenza elleni átoltottság elmarad az nemzetközi ajánlásoktól. A háziorvosok meggyőző potenciálja jelentős, ezért fontos szerepük van a felnőtt lakosság oltással kapcsolatos döntéseinek befolyásolásában.

Célkitüzés: Az influenza elleni oltásra vonatkozó támogató és akadályozó tényezők azonosítása felnőtt háziorvosok és a teljes lakosság és körében.

Módszer: 1000 fó, a teljes felnőtt lakosságra reprezentatív alany, valamint 317 fó, felnőtt- és vegyes praxisban dolgozó háziorvosokra reprezentatív orvos megkérdezése önkitöltős online kérdőív segítségével.

Eredmények: Az influenza elleni oltás lehetősége 93\%-ban ismert a lakosság számára, 30\% a leginkább a háziorvos tanácsát követné ebben a kérdésben. A háziorvosok jelentősen túlbecsülik az ellátott lakosság átoltottságát. Az oltást nem tervezők leggyakoribb indokai: nem tartják veszélyesnek az influenzát, bíznak a saját immunrendszerükben, tartanak az oltás mellékhatásaitól.

Megbeszélés: Elenyésző az influenza elleni oltás lehetőségét mereven elutasítók aránya. A többség relatív indokok alapján tartja kevésbé fontosnak ezt a lehetőséget. A háziorvos hiteles szereplő a lakosság jelentős része számára.

Következtetés: A háziorvos szerepe kulcsfontosságú a lakosság átoltottságának növelésében.
\end{abstract}

Orv Hetil. 2021; 163(6): 222-228.

Kulcsszavak: influenza elleni oltás, attitűd, háziorvos, meggyőző kommunikáció

\section{Influenza vaccination: pros and cons?}

\section{Views of general practitioners and the general population}

Introduction: Compared to the international guidelines, the flu vaccination rate of the Hungarian adult population is not satisfactory due to its heterogeneous attitude towards vaccination. Based on previous results, the convincing potential of general practitioners seems to be significant, therefore they have an important role when influencing people's decision-making concerning this topic.

Objective: To identify drivers and barriers to flu vaccination among general practitioners and the whole population. Method: Adult subjects representing the whole general population $(\mathrm{n}=1000)$, and a representative sample of general practitioners $(n=317)$ surveyed through online self-completed questionnaires.

Results: 93\% of the adult population is aware of influenza vaccine's existence. $30 \%$ prefer to follow the general practitioner's advice on this topic. General practitioners significantly over-estimate the vaccination coverage of the population they serve. The most common reasons for not getting vaccinated against flu: not considering the influenza dangerous, trusting their own immune system, and being afraid of the side effects of the vaccine.

Conclusion: The rate of hard refusal of influenza vaccination is negligible. The vast majority of the population consider this option less important for relative reasons. The general practitioner is an authentic actor for a large part of the population.

Keywords: influenza vaccination, attitude, general practitioner, convincing communication

Eörsi D, Gács Zs, Kun E. [Flu vaccination: pros and cons? Views of general practitioners and the general population]. Orv Hetil. 2022; 163(6): 222-228.

(Beérkezett: 2021. szeptember 19.; elfogadva: 2021. szeptember 29.) 


\section{Rövidítések}

CAWI $=$ (computer-assisted web interviewing) számítógéppel segített online kérdőíves felmérés; COPD = (chronic obstructive pulmonary disease) krónikus obstruktív tüdőbetegség; COVID-19 = (coronavirus disease 2019) koronavírus-betegség 2019; KSH = Központi Statisztikai Hivatal

Az influenza közismert, elsősorban a légutakat támadó fertőző betegség, melynek tünetei döntő többségben a láz és a köhögés, továbbá az ízületi és izomfájdalmak, a fejfájás, a torokfájás és a nátha [1]. Az esetek többségében orvosi beavatkozás nélkül spontán gyógyul, azonban világszerte évente 3-5 millió felnőtt kórházi ellátást igényel az influenza miatt, és sajnos 250 000-500 000 halálos áldozata is van a betegségnek [2]. A többlethalálozási adatok alapján történő becslés szerint hazánkban évente - jelentős szórás mellett - 1000 és 6000 közötti halálesetért felelős ez a kórkép [3]. A halálos, illetve súlyos lefolyású influenzafertőzés rizikótényezői elsősorban az életkor és egyes krónikus alapbetegségek, így a krónikus légúti betegségek, az immunszupprimált állapot és a cardiovascularis betegségek [4]. Az influenza okozta jelentős társadalmi egészségterhelés csökkentésének legfontosabb eleme az Egészségügyi Világszervezet (WHO) irányelve szerint a minél szélesebb körü, elsősorban a rizikócsoportokra fókuszáló évenkénti vakcináció (https://www.euro.who.int/en/health-topics/ communicable-diseases/influenza/seasonal-influenza).

A kockázati csoportok tagjainak átoltása fokozódó kihívást jelent. Magyarországon 2020-ban a KSH adatai szerint 197666665 éves vagy annál idősebb ember élt, ehhez képest csak 438245 térítésmentes influenzaoltást adtunk be ebben a magas kockázatú korcsoportban, ami 22,17\%-os átoltottságot jelent. (A hazai átoltottsági adatok a Nemzeti Népegészségügyi Központ Járványügyi és Infekciókontroll Főosztálya vezetőjének, dr. Molnár Zsuzsannának a szíves közlése alapján állnak rendelkezésünkre. A rizikócsoportokban történő átoltottság érdemben változatlan a 2015/2016-os és az azt követő négy szezon összevetése alapján.) A feldolgozott adatok alapján nem kiemelkedő az átoltottsági arány más rizikócsoportokban, így az egészségügyi dolgozók körében sem. (A KSH 2018. évi foglalkoztatási kimutatása szerint 122 000-en dolgoztak az egészségügyben, ehhez képest a 2018/2019-es szezonban 36168 egészségügyi dolgozó részesült államilag támogatott, influenza elleni védőoltásban, ami 29,64\%-os átoltottságot jelent.) Megjegyzendő, hogy más betegségek elleni vakcinációval kapcsolatban is azt látjuk, hogy az oltás lehetőségének ismerete nem feltétlenül társul a vakcináció melletti nagy arányú elköteleződéssel.

A nem megfelelő átoltottság soktényezős jelenség, melynek hátterében logisztikai, kommunikációs és gazdasági tényezők mellett a célcsoport tagjainak heterogén attitűdje is azonosítható. Célszerű megkülönböztetni egymástól az oltásokkal kapcsolatos bizonytalanságot
( „vaccination hesitancy”) és az oltások kemény elutasítását („vaccination refusal”) [5]; az előbbi csoport tagjai könnyebben győzhetők meg egy oltás szükségességéről. Ebből a szempontból kulcsszereplőnek tünik a háziorvos, aki az egyik leghitelesebb szereplő a lakosság számára egészségügyi kérdésekben [6,7], emellett az egészségügyi szakemberek által szerkesztett online és nyomtatott források olvasottsága is igen magas $[6,7]$. A COVID-19-világjárvány során egy vírusok okozta fertőző betegség és annak oltással történő megelőzése talán a legnagyobb hangsúlyt kapó témává lépett elő a közbeszédben, és remélhetjük, hogy mindez pozitív hatással lesz más hasonló betegségek, így az influenza elleni küzdelemre is.

Jelen kutatásunk célja, hogy megértsük a teljes lakosság és ezen belül a felnőtt- és vegyes praxisban dolgozó háziorvosok influenzavakcinációs attitüdjének aktuális állapotát. Ezen belül keressük a választ arra, hogy menynyire ismert az influenza elleni vakcináció lehetősége, illetve melyek azok a támogató és akadályozó tényezők, amelyek meghatározzák a lakosság affinitását ehhez a kérdéshez.

\section{Célcsoport és módszer}

Az önkitöltős online keresztmetszeti kérdőíves felmérés (computer-assisted web interviewing - CAWI) kérdőíveit kutatószociológusból és gyógyszeripari szakemberből álló munkacsoport dolgozta ki, és gyakorló háziorvos, illetve gyermekorvos véleményezését követően alakultak ki a végleges kérdőívek. Az összeállított kérdőíveket a

1. táblázat | A lakossági minta összetétele

\begin{tabular}{ll}
\hline A nők aránya & $51 \%$ \\
\hline Korcsoportos megoszlás & $31 \%$ \\
\hline $18-35$ éves & $25 \%$ \\
$36-50$ éves & $20 \%$ \\
$51-60$ éves & $23 \%$ \\
61 évesnél idősebb & $18 \%$ \\
\hline A lakóhely típusa & $21 \%$ \\
\hline Budapest & $32 \%$ \\
Megyei jogú város & $30 \%$ \\
Város & \\
Kisebb település & $40 \%$ \\
\hline Területi megoszlás & $30 \%$ \\
\hline Kelet-Magyarország & $30 \%$ \\
Nyugat-Magyarország & $37 \%$ \\
\hline Közép-Magyarország & \\
\hline Végzettség & $23 \%$ \\
\hline Felsőfokú & \\
\hline Középfokú & \\
\hline Alapfokú & \\
\hline
\end{tabular}


2. táblázat |A háziorvosi minta összetétele

\begin{tabular}{ll}
\hline A nók aránya & $51 \%$ \\
\hline Korcsoportos megoszlás & $15 \%$ \\
\hline 45 év alatti & $17 \%$ \\
$45-54$ éves & $30 \%$ \\
$55-65$ éves & $38 \%$ \\
65 évnél idősebb & \\
\hline A praxis lokalizációja & $19 \%$ \\
\hline Budapest & $19 \%$ \\
Megyei jogú város & $31 \%$ \\
Város & $31 \%$ \\
Kisebb település & \\
\hline Területi megoszlás & $37 \%$ \\
\hline Kelet-Magyarország & $34 \%$ \\
Nyugat-Magyarország & $29 \%$ \\
Közép-Magyarország & \\
\hline
\end{tabular}

célcsoporton próbalekérdezésnek vetettük alá, amit apróbb fogalmazásbeli módosítások követtek. A kutatásban való részvétel önkéntes volt, és az adatok anonim, összesített módon kerültek elemzésre.

Az adatfelvétel 2021 márciusában zajlott. Lakossági kutatásunk 1000 fős mintája nemre, életkorra, településtípusra, a lakóhely regionális eloszlására és végzettségre nézve reprezentatív a felnőtt magyar lakosságra (1. táb- lázat). A kutatásban részt vevők 41\%-a valamilyen, az influenza szempontjából emelt rizikófaktorú csoportba tartozott. (Önbevallás alapján a következő rizikófaktorok jelennek meg mintánkban: asztma/COPD, egyéb tüdőbetegség, szív- és érrendszeri betegség [beleértve a magas vérnyomást is], diabetes/cukorbetegség, gyengült immunitás.)

A 317, felnőtt- és vegyes praxisú háziorvost felölelő minta reprezentatív a felnőtteket kezelő háziorvosokra (2. táblázat). Átlagosan 25,3 éve praktizáltak a kutatásban részt vevő orvosok.

\section{Eredmények}

\section{Az oltások ismertsége és igénybevétele}

A lakossági kérdőívben 8 betegség kapcsán kérdeztük a válaszadókat, hogy tudomásuk szerint létezik-e ellenük védőoltás, illetve beadatták-e már vagy tervezik-e beadatni maguknak azt (3. táblázat).

A két legismertebb vakcina az influenza elleni (93\%) és a COVID-19 elleni (88\%) volt, és ezeket is adatták be, illetve tervezik beadatni a legnagyobb arányban $(47 \%$, illetve $51 \%)$. A további vakcinák ismertsége és beadatási hajlandósága lényegesen alacsonyabb.

A 2020. évi influenzaszezonban a felnőtt válaszadók 17\%-a oltatta be magát saját bevallása szerint, 2019-ben 14\%-uk és 2018-ban szintén 17\%-uk. A 3 vizsgált évben emlékei szerint legalább egyszer beoltatta magát a laikus válaszadók 24\%-a (4. táblázat).

3. táblázat $\mid$ Az oltások ismertsége és igénybevétele

\begin{tabular}{|c|c|c|c|c|c|c|c|c|}
\hline \multirow[t]{2}{*}{$(\%)$} & \multicolumn{3}{|c|}{$\begin{array}{c}\text { Ön szerint a következő betegségek } \\
\text { ellen létezik védőoltás? }\end{array}$} & \multicolumn{5}{|c|}{$\begin{array}{l}\text { Tudomása szerint Ön kapott nem kötelező védőoltást } \\
\text { a következő betegségek ellen? }\end{array}$} \\
\hline & $\begin{array}{c}\text { Létezik } \\
\text { ellene } \\
\text { védőoltás }\end{array}$ & $\begin{array}{l}\text { Nem } \\
\text { létezik }\end{array}$ & $\begin{array}{l}\text { Nem } \\
\text { tudom }\end{array}$ & $\begin{array}{l}\text { Már } \\
\text { megkaptam }\end{array}$ & $\begin{array}{l}\text { Meg fogom } \\
\text { kapni }\end{array}$ & $\begin{array}{c}\text { Nem és } \\
\text { nem is } \\
\text { fogok kapni }\end{array}$ & $\mathrm{NT} / \mathrm{NV}$ & $\begin{array}{l}\text { Nincs ilyen } \\
\text { védőoltás }\end{array}$ \\
\hline & \multicolumn{8}{|c|}{$\mathrm{n}=1000$} \\
\hline Influenza elleni oltás & 93 & 2 & 5 & 24 & 23 & & 8 & 2 \\
\hline COVID-19 elleni oltás & 88 & 5 & 6 & 13 & 38 & 29 & 15 & 5 \\
\hline HPV elleni oltás & 75 & 4 & 21 & 12 & 1 & 53 & 30 & 4 \\
\hline $\begin{array}{l}\text { Kullancs terjesztette agyhártyagyulladás } \\
\text { elleni oltás }\end{array}$ & 75 & 8 & 18 & 11 & 2 & 50 & 29 & 8 \\
\hline Rotavírus elleni oltás & 70 & 4 & 25 & 8 & 1 & 55 & 31 & 4 \\
\hline $\begin{array}{l}\text { Gennyes agyhártyagyulladás B-típusa } \\
\text { elleni oltás }\end{array}$ & 62 & 6 & 32 & 8 & 1 & 51 & 34 & 6 \\
\hline $\begin{array}{l}\text { Gennyes agyhártyagyulladás C-típusa } \\
\text { elleni oltás }\end{array}$ & 58 & 7 & 35 & 8 & 1 & 51 & 33 & 7 \\
\hline Pneumococcus elleni oltás & 47 & 7 & 46 & 6 & 1 & 44 & 42 & 7 \\
\hline
\end{tabular}

COVID-19 = koronavírus-betegség 2019; HPV = humán papillomavírus

Megjegyzés: Az influenza elleni oltás beadatását, illetve tervezését külön kérdésekben mértük fel, amelyekben az elmúlt 3 évre részletesen kérdeztünk rá. Az ott kapott válaszok összesítését mutatjuk itt be:

- Már megkaptam = az elmúlt 3 évben legalább egyszer beadatta

- Meg fogom kapni = feltétlenül vagy valószínúleg szándékában áll beoltatni magát influenza ellen a következő szezonban (1-5-ös skálán)

- NT/NV = nem tudja, hogy beoltatja-e magát influenza ellen a következő szezonban 
Felmérés a 2019. évi, influenza elleni oltásról

\begin{tabular}{lccc}
\hline Ön be lett oltva az influenza ellen 2019-ben? & & \\
\hline Igen & Nem & $\begin{array}{c}\text { Nem } \\
\text { emlékszem }\end{array}$ \\
\hline & \multicolumn{3}{c}{$\mathrm{n}=1000$} \\
\hline $\begin{array}{l}\text { 18-60 éves, NEM fokozottan } \\
\text { veszélyeztetett kockázati csoport }\end{array}$ & 8 & 87 & 5 \\
$\begin{array}{l}60 \text { évesnél idősebb VAGY fokozottan } \\
\text { veszélyeztetett kockázati csoport }\end{array}$ & 21 & 76 & 3 \\
\hline
\end{tabular}

5. táblázat | A 2019. évi, influenza elleni védőoltással kapcsolatos korosztályos megoszlás

Ha az egyes korosztályokra gondol, körülbelül pácienseinek hány százaléka kapta meg az influenza elleni védőoltást 2019-ben?

\begin{tabular}{lcccc}
\hline (\%) & $\begin{array}{c}\text { Vaxigrip } \\
\text { Tetra }\end{array}$ & Fluart & $\begin{array}{c}\Sigma \\
\text { oltott }\end{array}$ & $\begin{array}{c}\text { Nem } \\
\text { oltott }\end{array}$ \\
\hline $\begin{array}{l}\text { 19-60 éves, NEM fokozottan } \\
\text { veszélyeztetett kockázati csoport }\end{array}$ & 3 & 23 & 26 & 74 \\
$\begin{array}{l}60 \text { évesnél idősebb VAGY } \\
\text { fokozottan veszélyeztetett } \\
\text { kockázati csoport }\end{array}$ & 4 & 43 & 47 & 53 \\
\hline
\end{tabular}

A háziorvosok becslése alapján a 60 év alatti, rizikócsoportba tartozó páciensek 26\%-a, a 60 év felettiek 47\%-a kapott influenza elleni védőoltást a 2019/2020-as szezonban (5. táblázat).

\section{Ajánlás és döntés az influenza elleni védőoltás beadatásáról}

A következő kérdéskör azt vizsgálta, hogy mely szereplő véleménye, tanácsa számít a leginkább a vizsgált lakossági populáció számára az influenzaoltás vállalása szem- pontjából. A direkt kérdést követően (1. ábra) elemeztük, hogy mennyire térnek el a legutóbbi szezonban magukat influenza ellen oltatók és nem oltatók emlékei a különböző csatornákon hallott vagy látott ajánlások kapcsán, illetve melyek voltak a legnyomósabb érvek döntéseik mellett. Ugyancsak megvizsgáltuk azt, hogy a háziorvosi ajánlások kapcsán mennyire egyeznek meg vagy térnek el egymástól a lakossági és a háziorvosi minta emlékei.

A lakossági válaszadók 30\%-a leginkább a háziorvosa tanácsát fogadná el azért, hogy beoltassa magát az influenza ellen, más szereplők ajánlása ennél kevesebbet nyom a latban.

Bár a háziorvosok 95\%-a véli úgy, hogy rendszeresen és aktívan ajánlja az influenza elleni védőoltást páciensei számára, a lakossági kutatásban részt vevők 27\%-a számolt be háziorvosi ajánlásról az elmúlt szezonban, további 5\%-nak egyéb egészségügyi szakember javasolta.

A magukat valóban beoltatók 62\%-ának javasolta vagy legalább említette az influenzaoltást a háziorvosa - ami szignifikánsan magasabb arány, mint a nem oltatók körében tapasztalt, ám az egészségügyi szakemberek ajánlását csupán $16 \%$ jelölte meg mint nyomós indokot az oltás felvételére. Akik viszont nem oltatták be magukat, azok 11\%-a említette indokként az ajánlások hiányát, és csupán 20\%-uk említette, hogy háziorvosuk javasolta, oltassák be magukat.

Ugyancsak szignifikánsan nagyobb arányban említették a magukat oltatók, hogy a szezonális influenzaoltás beadatásáról hallottak szakorvosoktól ( $9 \%$ vs. 2\%), a hatóságoktól ( $12 \%$ vs. $5 \%)$ vagy egészségügyi szakemberektől $(11 \%$ vs. 6\%) a médián keresztül, illetve a cégnél a foglalkozás-egészségügyért felelős szakembertől (6\% vs. 3\%), mint a magukat nem oltatók (6. táblázat).

További két kérdésünkkel az oltottak (4. táblázat) és a nem oltottak (7. táblázat) körében vizsgáltuk az oltás felvételének, illetve elkerülésének legfontosabb okait.

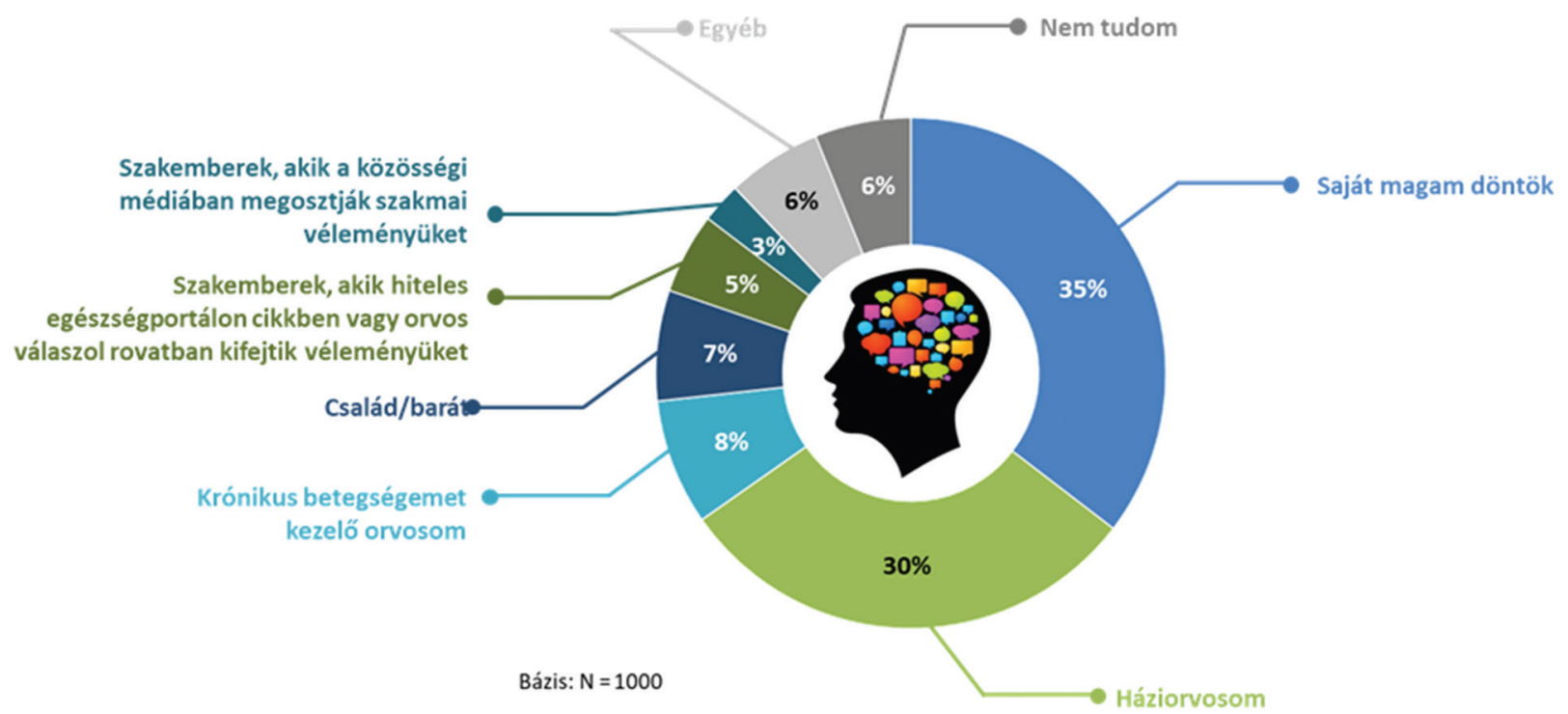

1. ábra | A válaszadók megoszlása aszerint, hogy kinek a tanácsát fogadnák el a leginkább abban a kérdésben, hogy beoltassák-e magukat influenza ellen 
6. táblázat

Az influenza ellen 2020-ban beoltottak válaszai

Mi volt az öt legfontosabb oka annak, hogy beoltatta magát influenza ellen a 2020-as szezonban? Legfeljebb 5 okot jelölhet meg. (\%)

\begin{tabular}{|c|c|c|c|}
\hline \multicolumn{2}{|l|}{ Fő kategória } & \multicolumn{2}{|l|}{$\begin{array}{l}\text { Részletes válaszok } \\
\text { (10\% feletti említések) }\end{array}$} \\
\hline \multicolumn{4}{|c|}{$\mathrm{n}=165-$ akik oltattak infuenza ellen 2020-ban } \\
\hline \multirow{7}{*}{$\begin{array}{l}\text { Az influenza } \\
\text { percepciójához } \\
\text { kapcsolódó } \\
\text { válaszok }\end{array}$} & 36 & $\begin{array}{l}\text { Az influenza miatt kórházba } \\
\text { kerülhetek }\end{array}$ & 12 \\
\hline & & Az influenza gyakori betegség & 21 \\
\hline & & $\begin{array}{l}\text { Az influenza minden évben } \\
\text { elófordul }\end{array}$ & 29 \\
\hline & & $\begin{array}{l}\text { Nem kívánok komplikációkat } \\
\text { az influenza miatt }\end{array}$ & 41 \\
\hline & & Félek az influenzától & \\
\hline & & $\begin{array}{l}\text { Ha már a COVID-19 ellen nem } \\
\text { kaphattam oltást, legalább az } \\
\text { influenza ellen védett legyek }\end{array}$ & 12 \\
\hline & & $\begin{array}{l}\text { A COVID-19 és az influenza } \\
\text { együtt súlyosabb lehet }\end{array}$ & 37 \\
\hline \multirow{2}{*}{$\begin{array}{l}\text { Az influenzaoltás } \\
\text { percepciója és } \\
\text { ajánlása }\end{array}$} & 83 & $\begin{array}{l}\text { Az orvos/nővér/gyógyszerész } \\
\text { javasolta, hogy oltassam be magam }\end{array}$ & 16 \\
\hline & & $\begin{array}{l}\text { Adok a véleményére annak, } \\
\text { aki ajánlotta, hogy oltassam be } \\
\text { magam }\end{array}$ & 12 \\
\hline \multirow[t]{3}{*}{ Személyes indokok } & 76 & Krónikus betegségben szenvedek & 30 \\
\hline & & $\begin{array}{l}\text { Nem akarom megfertózni a } \\
\text { családomat, barátaimat, munkatár- } \\
\text { saimat }\end{array}$ & 29 \\
\hline & & $\begin{array}{l}\text { Mindig be szoktam magam oltatni } \\
\text { influenza ellen }\end{array}$ & 38 \\
\hline $\begin{array}{l}\text { Más betegséggel } \\
\text { keveri }\end{array}$ & 10 & $\begin{array}{l}\text { Hogy megelózzem } \\
\text { a COVID-19-et }\end{array}$ & 10 \\
\hline \multirow[t]{2}{*}{ Anyagi okok } & 42 & $\begin{array}{l}\text { Ingyen kaphattam influenza } \\
\text { elleni oltást a társadalombiztosítás } \\
\text { (tb/OEP) keretében }\end{array}$ & 28 \\
\hline & & $\begin{array}{l}\text { Nem akarok betegszabadságra } \\
\text { menni/nem akarom, hogy } \\
\text { jövedelmem essen ki }\end{array}$ & 11 \\
\hline
\end{tabular}

COVID-19 = koronavírus-betegség 2019; OEP = Országos Egészségbiztosítási Pénztár (ma Nemzeti Egészségbiztosítási Alapkezelő); tb = társadalombiztosítás

A legnagyobb arányban említett indokok az oltás beadatására a komplikációktól való félelem, a megszokás, illetve az aggodalom, hogy a COVID-19 és az influenza együtt súlyosabbak lehetnek.

\section{Megbeszélés, következtetések}

Kutatásunk alapján úgy látjuk, hogy az influenza elleni vakcináció mint lehetôség jól ismert a magyar lakosság körében, a válaszadók 93\%-a tud erról az eszközről. Ez kiemelkedően magas aránynak számít, jelentősen meghaladja valamennyi más, a kérdőívben szereplő oltóanyag
7. táblázat |Az influenza ellen 2020-ban be nem oltottak válaszai

Mi volt az öt legfontosabb oka annak, hogy nem oltatta be magát influenza ellen a 2020-as szezonban? Legfeljebb 5 okot jelölhet meg. (\%)

\begin{tabular}{|c|c|c|c|}
\hline \multicolumn{2}{|l|}{ Fő kategória } & \multicolumn{2}{|l|}{$\begin{array}{l}\text { Részletes válaszok } \\
\text { (10\% feletti említések) }\end{array}$} \\
\hline \multicolumn{4}{|c|}{$\mathrm{n}=801$ - akiket nem oltottak influenza ellen 2020-ban } \\
\hline \multirow{2}{*}{$\begin{array}{l}\text { Az influenza } \\
\text { percepciójához } \\
\text { kapcsolódó válaszok }\end{array}$} & \multirow[t]{2}{*}{37} & Az influenza enyhe betegség & 20 \\
\hline & & Sosem voltam még influenzás & 20 \\
\hline \multirow{3}{*}{$\begin{array}{l}\text { Az influenzaoltás } \\
\text { percepciója és } \\
\text { ajánlása }\end{array}$} & \multirow[t]{3}{*}{53} & $\begin{array}{l}\text { A gyógyszeres kezelés/megelőzés } \\
\text { elegendő }\end{array}$ & 19 \\
\hline & & Az influenzaoltás nem hatékony & 10 \\
\hline & & $\begin{array}{l}\text { Az esetleges mellékhatások miatt } \\
\text { nem oltatom magam }\end{array}$ & 23 \\
\hline \multirow[t]{3}{*}{ Személyes indokok } & \multirow[t]{3}{*}{69} & $\begin{array}{l}\text { Egészséges vagyok/nincs } \\
\text { szükségem az oltásra }\end{array}$ & 36 \\
\hline & & Mindig elhanyagolom/elfelejtem & 10 \\
\hline & & $\begin{array}{l}\text { Keveset érintkezem másokkal, nem } \\
\text { valószínú, hogy elkapom }\end{array}$ & 17 \\
\hline Anyagi okok & 12 & - & \\
\hline Külső tényezôk & 28 & $\begin{array}{l}\text { A COVID-19 miatt kockázatos- } \\
\text { nak tartom, hogy orvoshoz } \\
\text { menjek }\end{array}$ & 10 \\
\hline
\end{tabular}

Az ajánlások hiánya 11

miatt

COVID-19 = koronavírus-betegség 2019

ismertségét is (még a COVID-19 elleni oltás ismertségénél is magasabb, ami azért figyelemre méltó, mert az adatfelvétel idópontja egybeesik a COVID-19 elleni országos vakcinációs tömegkommunikációs kampány idejével).

Az influenza elleni vakcináció lehetőségének magas ismertsége azonban nem párosul hasonlóan magas átoltottsággal még a kockázati csoportba tartozók körében sem. Sajnos elmondhatjuk, hogy az influenza elleni átoltottságot évek óta nem a rendelkezésre álló oltóanyag mértéke limitálja, hanem az oltásra jelentkezők viszonylag alacsony száma, ezért a vakcinációhoz való hozzáférési lehetőségek és a motivációk további elemzése, megértése szükséges a magasabb átoltottsági arány eléréséhez.

Figyelemre méltó adat, hogy a megkérdezett háziorvosok messze felülbecsülik az általuk ellátott lakosság influenza elleni átoltottságát, például a 65 év feletti lakosság mintegy felét becsülik átoltottnak - miközben a valóságban ettől lényegesen elmarad az átoltottsági arány.

A megkérdezett lakossági válaszadók viszonylag nagy arányban vélik úgy, hogy az egészségügyi szakemberek, ezen belül a háziorvosok ajánlása nagyban befolyásolja az influenza elleni oltás irányában megélt motivációjukat. További vizsgálatot igényel a háziorvosok percepciója a témában, hiszen motivációjuk indokolatlanul alacsony nívón maradhat, ha túlbecsülik ajánlási tevé- 
kenységüket. Kiemelendő, hogy az oltásban ténylegesen részesültek körében szignifikánsan magasabb ez az arány, mint azok körében, akik végül nem kaptak oltást influenza ellen.

Kutatásunk kitért azon támogató és akadályozó tényezők elemzésére is, amelyek a legnagyobb valószínűséggel alakítják a lakosság influenzavakcinációra irányuló attitüdjét. Az oltásban nem részesülők távolmaradásának okát kutatva arra jutottunk, hogy elhanyagolható azok aránya, akik eleve elutasítják az oltást mint lehetőséget, esetleg veszélyesnek, gyógyszergyárak által manipuláltnak tartják az elérhető vakcinákat, tehát merev oltásellenesség, oltástagadás minimális mértékben volt kimutatható mintánkban. Sokkal nagyobb arányban szerepelnek a „puha”, relatív ellenérvek, például sokan nem tartják annyira veszélyes betegségnek az influenzát, hogy oltással kellene ellene védekezni (20\%), saját egészségükben bíznak (36\%), illetve elismerik, hogy el szoktak feledkezni erről a lehetőségről (10\%).

$\mathrm{Az}$ oltásban részesülők körében a legnagyobb arányban az influenza szövődményeinek megelőzése iránti szándék szerepel mint motiváció (41\%), de hangsúlyos például a család védelmének vágya is (29\%). Az egészségügyi szakemberek ajánlását ennél kisebb arányban (16\%) jelölték meg a válaszadók.

Mindennek alapján az látható, hogy a lakosság ismeri az influenza elleni védőoltás lehetőségét, de jelentős részben ambivalens ezzel kapcsolatban. Az egészségügyi szakemberek, ezen belül a háziorvosok ajánlása fontos motiváló tényező lehet, ezt a lehetőséget azonban nem használjuk ki teljes mértékben. A 2019/2020-ban kezdődött COVID-19-világjárvány sosem látott mértékben a közbeszéd fókuszába helyezte az oltások jelentőségét, remélhetjük, hogy ez új lendületet fog adni a témáról zajló egészségkommunikációnak.

\section{Ajánlás}

Az oltások és így az influenzaoltás társadalmi elutasításával kapcsolatos leggyakoribb szakmai elóítélet az, hogy a társadalom oltásellenes tagjait úgysem lehet meggyőzni. Kétségkívül vannak, akik világnézeti vagy egyéb alapon mélyen elutasítják az oltások lehetőségét, a többség esetében azonban ennél egyszerúbb, „puhább” okokból marad el az ajánlott oltás beadása. Ezért javasolható, hogy a praktizáló háziorvosok tartsák célkitűzésnek, hogy a rizikócsoportokba tartozó pácienseik minél nagyobb arányban be legyenek oltva az influenza ellen is nem véletlen, hogy az alapellátó praxisok minőségi indikátorai közül is az idős lakosság influenza ellen történő immunizálása az egyik.

A következő kommunikációs stratégiákat ajánljuk [8]:

- Lehetőleg valamennyi, rizikócsoportba tartozó páciensünknél hozzuk szóba az influenzaoltás lehetőségét.

- Amennyiben ellenállást, ambivalenciát tapasztalunk, javasolt racionális és érzelmi úton is kísérletet tenni a páciens meggyőzésére. Racionális érvelésünk során mindig az influenzabetegség kockázatait helyezzük előtérbe, emellett emeljük ki és természetesen ismertessük az oltás kockázatait is. Az érzelmi úton történő meggyőzés keretein belül javasolt az énközlések, a vakcsoport-módszer és a szendvicstechnika alkalmazása.

Énközlésen azt értjük, hogy verbalizáljuk személyes elkötelezettségünket, ezáltal fejezzük ki, hogy a páciens oldalán állunk akkor, amikor meg akarjuk győzni az oltás elfogadásáról. Például:

„Szeretném, ha Ön is védett lenne az influenza ellen.” "Aggódnék Önért, ha influenzás lenne."

- A vakcsoport-módszer során a pácienst egy olyan fiktív, pozitív tulajdonsággal jellemezhető csoport tagjaként mutatjuk be, amelynek tagjai számára norma az oltás felvétele. Például:

„Az olyan felvilágosult emberek, mint Ön, fel szokták venni az influenza elleni védőoltást.”

„Mi, akik felelősséggel tartozunk a családunkért/környezetünkért, beoltatjuk magunkat."

- A szendvicstechnika pedig valójában három mondatrészből áll: az első és az utolsó azt a szempontot fejezi ki, amelyikről a pácienst meg kívánjuk győzni, a középső pedig egy empatikus közlés arra vonatkozóan, hogy értjük, az ő oldaláról mi okozhat ellenállást. Például:

„Az influenzaoltás Önnek is javasolt. Sokan tartanak az oltástól, azonban sokkal kisebb az oltásból adódó kockázat, mint az influenza szövődményeinek kockázata."

Anyagi támogatás: A közlemény elkészítése anyagi támogatásban nem részesült. A kutatást a Szinapszis Kft. végezte, az adatfelvételt a Sanofi Pasteur támogatta, azonban sem a Sanofi Pasteurnak, sem más külső szereplőnek nincs szava tartalmi kérdésekben.

Szerzői munkamegosztás: Eö. D.: Háttér, értelmezés, következtetések. G. Zs.: Szupervízió, következtetések. K. E.: Minta és módszer, adatelemzés, értelmezés. A cikk végleges változatát valamennyi szerző elolvasta és jóváhagyta.

Érdekeltségek: A szerzőknek nincsenek érdekeltségeik.

\section{Irodalom}

[1] Paules C, Subbarao K. Influenza. Lancet 2017; 390(10095) 697-708.

[2] World Health Organization. Global influenza strategy 20192030. Available from: https://www.who.int/influenza/Global_ Influenza_Strategy_2019_2030_Summary_English.pdf [accessed: Sept 27, 2021].

[3] Kovács K, Pakot L. Influenza-associated mortality in Hungary between 2009/2010 and 2016/2017. [Influenzához kapcsolódó halálozás 2009/2010 és 2016/2017 között Magyarországon.] Orv Hetil. 2020; 161: 962-970. [Hungarian] 
[4] Mertz D, Kim TH, Johnstone J, et al. Populations at risk for severe or complicated influenza illness: systematic review and meta-analysis. BMJ 2013; 347: f5061.

[5] Cerda AA, García LY. Hesitation and refusal factors in individuals' decision-making processes regarding a coronavirus disease 2019 vaccination. Front Public Health 2021; 9: 626852

[6] Kun E. Where do we gather medical informations from? Orientation habits of the whole population and general practitioners. [Honnan szerzünk egészségügyi információt? A lakosság és a háziorvosok digitális tájékozódási szokásai.] Gyógyszertár Magazin 2018; 17(5): 20-21. [Hungarian]
[7] Kis T. Research on internet-based medical information gather ing. [Kutatás az internetes egészségügyi információszerzésről.] 23. 12. 2016. Available from: https://www.szinapszis.hu/hu/ hirek/kutatas-az-internetes-egeszsegugyi-informacioszerzesrol [accessed: Sept 27, 2021]. [Hungarian]

[8] Pilling J. Medical communication in practice. [Orvosi kommunikáció a gyakorlatban.] Medicina Könyvkiadó, Budapest, 2018 [Hungarian]

(Eörsi Dániel dr., Budapest, Völgy u. 15.; 1021 e-mail: danieorsi@gmail.com)

A Semmelweis Egyetem Általános Orvostudományi Kara örömmel tesz eleget annak a hagyománynak, hogy volt diákjait jubileumi díszoklevéllel tünteti ki.

Kérjük ezért azokat az orvosokat, akik diplomájukat az egyetem jogelődjénél, a PÁZMÁNY PÉTER TUDOMÁNYEGYETEMEN, a BUDAPESTI ORVOSTUDOMÁNYI EGYETEMEN, illetve a SEMMELWEIS ORVOSTUDOMÁNYI EGYETEMEN
1947-ben
1952-ben
1957-ben
1962-ben
1972-ben

szerezték meg, és szakterületükön legalább 30 évig dolgoztak, nyújtsák be kérelmüket a platina, rubin, vas, gyémánt, illetve arany díszoklevél elnyerése érdekében 2022. április 30-ig, a következő címre, az alábbi jelentkezési lapon.

\section{Semmelweis Egyetem Általános - Orvostudományi Kar \\ Dékáni Hivatal \\ 1085 Budapest, Üllői út 26. vagy 1428 Budapest Pf. 2}

A jubileumi díszoklevelek átadására elöreláthatóan októberben kerül sor. A pontos időpontról meghívó útján küldünk értesitést.

\section{JELENTKEZÉSI LAP \\ arany, gyémánt, vas, rubin és platina díszoklevélhez}

NÉV

(névváltoztatás feltüntetésével)

Születési idő:

Diploma kelte:

Lakcím:

Telefonszám:

E-mail cím:

Utolsó munkahely:

Rövid szakmai önéletrajz:

Megismertem és elfogadom az adatkezelési tájékoztatóban foglaltakat.

Dátum:

\section{a kérelmező aláírása}

Aláirásommal hozzájárulok ahhoz, hogy a lakóhelyem szerinti illetékes önkormányzat megkeresésére, kerületi ünnepségre történő meghivás céljából az elérhetőségeim kiadásra kerüljenek.
A megfelelő válasz aláhúzandó.
IGEN
NEM

A cikk a Creative Commons Attribution 4.0 International License (https://creativecommons.org/licenses/by/4.0/) feltételei szerint publikált Open Access közlemény, melynek szellemében a cikk bármilyen médiumban szabadon felhasználható, megosztható és újraközölhető, feltéve, hogy az eredeti szerző és a közlés helye, illetve a CC License linkje és az esetlegesen végrehajtott módosítások feltüntetésre kerülnek. (SID_1) 